Studies in Travel Writing

\title{
"You want people to see you in all your nuanced variety": an interview with Noo Saro-Wiwa
}

\section{Nicklas Hållén \& Janet Remmington}

To cite this article: Nicklas Hållén \& Janet Remmington (2015) "You want people to see you in all your nuanced variety": an interview with Noo Saro-Wiwa, Studies in Travel Writing, 19:3, 274-282, DOI: $10.1080 / 13645145.2015 .1074812$

To link to this article: https://doi.org/10.1080/13645145.2015.1074812

曲 Published online: 15 Sep 2015.

Submit your article to this journal

Џlll Article views: 190

View Crossmark data \lceil 


\title{
"You want people to see you in all your nuanced variety": an interview with Noo Saro-Wiwa
}

Nicklas Hållén* and Janet Remmington

\begin{abstract}
Born in Nigeria in 1976, Noo Saro-Wiwa grew up in the UK. In 2008 she took a trip around the country of her birth. The journey resulted in her first book, Looking for Transwonderland: Travels in Nigeria (Granta, 2012). It was selected as BBC Radio 4's Book of the Week and the Sunday Times Travel Book of the Year in 2012. In this interview with Nicklas Hållén and Janet Remmington, Saro-Wiwa covers a range of topics and reflections, including (trans)national identities, readership and reception, the legacy of her father, Ken Saro-Wiwa, and the craft of travel writing. The interview incorporates questions and answers from two occasions: a face-to-face meeting in London in May 2014 and an audience-facing discussion at the University of York's "African Intellectual Mobilities" colloquium in February 2015.
\end{abstract}

Keywords: Noo Saro-Wiwa; Looking for Transwonderland (2012); Nigerian literature; diasporic travel literature; African travel literature; transnational identities

\section{The book and its reception ${ }^{1}$}

Nicklas Hållén: Could you briefly describe Looking for Transwonderland and the project it resulted from?

Noo Saro-Wiwa: Looking for Transwonderland is a book about my travels in Nigeria. I was born there but never lived there, and when my father [Ken Saro-Wiwa], who was a human rights activist, was killed [by the Nigerian government, in 1995] I really did not want to go back. When I was a child we used to go back during the summer holidays, so that was my experience of Nigeria. I stayed away from the country [after my father's death], but after I left school I did a lot of travel around Africa. I spent so much time in these countries that the thought of visiting Nigeria as an independent traveller appealed to me. It wasn't something I had considered previously because whenever I went back [as a child] it was always for family reasons. I knew I wanted to be a travel writer, so I thought I would combine the two things, that is, being the tourist and getting to know Nigeria in a different way (up until that point it was this terrible place - the place where my father was killed). I wanted to experience it in a way that was separate from the negative stuff. So that is how the book came about.

$N H$ : Did the fact that your father is a central figure in the book limit what you could write? And has it affected the way in which the book has been received?

$N S W$ : Obviously, having Ken Saro-Wiwa as my father was an advantage when it came to publicising the book. When I travelled around Nigeria, it did not come up that often in conversation. It would come up when someone saw my surname, and situations like that. I met a man who began talking about my father in disparaging terms, so I told him that he was my father. Under those circumstances I would reveal my identity. But for the most part I travelled around incognito.

*Corresponding author. Email: nicklas.hallen@lnu.se 
Every now and then I would meet someone who knew my surname and they would treat me very nicely as a result. So from a travel perspective it was neither a help nor a hindrance.

When I wanted to write about South Africa I saw myself as a Paul Theroux or Miranda France but other people saw me as simply the daughter of Ken Saro-Wiwa, which was frustrating. I felt I could not write the book that I wanted to publish first because of that. So it was a problem in that sense.

Janet Remmington: Could you tell us about your choice of title Looking for Transwonderland? Can you tell us more about this intriguing sounding place - Transwonderland - and its metaphoric potential?

$N S W$ : I am not very good at titles. I don't judge a book by its title and I am not interested in titles. I told my agent this [... ] I couldn't think of anything, but in our conversation she said, "What is this book about?" I said, "I just want to see this other side of Nigeria, Nigeria as a travel destination". 2

I didn't want Nigeria to be that place where I had to go every summer when I was a child and where my father was murdered. I wanted it to be like Ghana, Côte d'Ivoire and Gabon, and the other countries I had visited. I wanted to experience Nigeria in that way. My agent said, "Oh, you are looking for a different sort of ... " I had been talking about Nigeria as a place where they have tourist attractions and places like amusement parks. I was looking for that side of the country. So it was actually my agent who suggested Looking for Transwonderland. It perfectly encapsulates, as a metaphor, the purpose of my journey.

$N H$ : Did you have a book contract with Granta in advance and were your travels paid for by the publisher?

$N S W$ : I had already written a book about my travels around South Africa. That was going to be my first book, [but] my agent decided it would be better if I wrote about Nigeria first. Because of my name, she said people would ask, "why is she writing about South Africa?" I can understand that now, but at the time I did not. So we proposed Looking for Transwonderland to Granta (Nigeria was the second book I planned to write). In the end Granta offered a deal for both books, but I turned down the South Africa one. I scrapped it. So, yes, I went to Nigeria with a contract and Granta financed the travel.

$N H$ : Can you tell us a little bit about the process that led you to decide to write the book?

$N S W$ : Writing is something I have always wanted to do, but it took me a long time to figure out how that interest would manifest itself. I started off wanting to be a journalist. But within a week of journalism school I changed my mind. The stories that interested me weren't newsworthy; they don't make it into the papers. But neither did I want to write fiction. [ ... ]

I was about 25 when I decided I was going to be a travel writer. By then I had written travel guides for Rough Guide (I then went on to write for Lonely Planet). Writing travel guides is frustrating. I did it because I wanted to see the world for free. I am really glad that I did, because it threw me into the deep end. I was 22 when I went to Ivory Coast and Guinea for Rough Guide. I was terrified! I didn't speak French fluently and I had never been backpacking around Africa - I had never been backpacking full stop. Yet I had to write this travel guide. The concept of backpacking in Africa ... I had never heard of it. I was really scared. I did not know what to expect prior to that trip. But then I realised, "Oh they've got bed \& breakfasts too". So I took this trip around Cote d'Ivoire and Guinea. It was a pivotal experience because it took the fear out of travelling in Africa. But writing a travel guide was doing my head in! I was looking forward to travel around the continent, but in my own way.

So that was my reason for wanting to get into travel writing. But there was the personal side as well - my father's death. I had stayed away from Nigeria and wrote a book (which I decided not to publish) about my journeys around South Africa. After almost a year in South Africa I had a craving to travel around West Africa. [...] It suddenly hit me that I could actually make a 
similar journey in Nigeria. I didn't want to simply return to my hometown and see my family and dwell on my father's death. I thought: Nigeria is this whole country. It has rainforests and gorillas and mountains. Why not travel around there in the same way I had done in other parts of Africa?

$\mathrm{NH}$ : The book has received a lot of attention and been met with critical acclaim in Europe. What have the reactions been in Nigeria?

$N S W$ : I have received a lot of emails from Nigerians who loved Transwonderland. But there have been critics too. The reaction is like the two ends of a horseshoe spectrum: what people have against the book is the same as what people like about it. I guess I was writing for a diaspora audience, for people like me. That is who I had in mind when writing.

The best comment I heard encapsulated the different viewpoints. Someone said on Twitter "you will love the sharp writing and you will hate the truth of it" and I think that encapsulates it. I think a lot of the Nigerians who do not like it disapprove of a diasporan who: a) is talking about the country and b) complaining about it. They get very defensive, which is odd because Nigerians do nothing but complain about Nigeria. But when you put those complaints in a book, and you are someone who has been raised in England, they take umbrage.

There is a certain territoriality involved. Some people don't believe diasporans should have a voice. But I just try to be as honest as possible in my writing. When you are honest it is not about trying to be positive or negative. If you put down the truth as you see it, then it always involves a mix of both.

Also, there is a certain type of Nigerian who never travels. Even when they read a travelogue like Transwonderland they will not "travel" within it: they fixate on the city they know, whereas the Nigerians who loved the book say, "Wow! I didn't know this place existed in Nigeria". They are glad that I pointed it out.

I feel that people are not objective in their critique, whether it is positive or negative. There is a lot of emotion attached to it. Some readers focus on certain aspects of Transwonderland. Some talk about my relationship with my father and nothing else, as if it's solely a memoir. Some people treat it as an analysis of Nigerian society. There is a bit of analysis, but it is light - I just touched on things. I felt there were all those facets. Not everyone takes all of these facets on board. They may have the one thing that they like or dislike, and they dwell on that.

$N H$ : Did you ever worry about the reception in Nigeria before the book was published?

$N S W$ : No, I didn't think about it. As you get older you get more conscious of these things. I was thirty-one when I did the travel. Now I am thirty-nine. The younger you are, the less you think about things. In a way that is good, because with my next book I will probably be far more aware of readers" reactions. It is a good thing in some ways, but this sort of "wisdom" might change the way I write. So no, I didn't think about it: I had real tunnel vision. I wrote Transwonderland for my friends, for diasporic Nigerians like me. I didn't consider the wider audience.

$J R$ : It is an interesting point: about awareness of audience, readership. To what degree do you take into consideration your constituencies and whether it is a good thing or a bad thing to be aware of your readers?

$N S W$ : I don't like reading what I have written, because I know can't change anything!

If I could, I would explain my opinions a lot more. Some Nigerians are very defensive, so you have to take that defensiveness into account. I would express the same opinions, but explain them in more detail, so that nothing is misconstrued - because that is what happens when people are defensive: they make strange interpretations of what you write.

$J R$ : Do you think that anxiety about pleasing a readership affects good writing?

$N S W$ : Yes. You should always be true to yourself. Having said that, it's good to be mindful that your readers might misinterpret your outlook. For example, one online reviewer believed I wanted Nigeria to be like the West, which isn't true. When writing Transwonderland, I assumed that my 
readers would be diasporans like me, so I didn't expand on my opinions as much as I could have done. It's good to add a little more explanation, especially as some Nigerians can be very defensive.

I was having an argument with my auntie about prayer. She was saying, "You need prayer. Europe is going down the toilet because they don't pray" and I [said]: "Well I think that society is better because they don't pray". Things like that. Of course, there is plenty I find wrong with Western society, but I didn't put that in the book, because it wasn't relevant to the conversation. But because I didn't put it in the book, some people get the wrong impression. Things like that.

\section{Identity and the Nigerian diaspora}

$J R$ : I really like the way that the book opens with full immersion into the experience at the departure lounge of the airport. The experience at the beginning of the book is about a delayed plane to Lagos. You find yourself, as a narrator, in the departure lounge. I am just going to read a short section here:

[Airports] are [... ] places where, as a Nigerian raised in England, I'm forced to watch the European and African mindsets collide in a way that equally splits my loyalty and disdain towards both: I wanted to spank that Italian for misunderstanding our behaviour and revelling in his sense of superiority; I also cringed at the noisy Nigerian passengers for their paranoia, ill-discipline and obliviousness to British cultural norms. $(2012,3)$

The airport is a kind of threshold between places and perhaps between identities. I am interested in the way you demarcate two sides, if you will, right from the beginning of the book. Can you describe how you move from this point in the story and explore the question of conflicting allegiances?

$N S W$ : I have had a lot of people from various nationalities tell me they have felt the same way. My English friends, they identify [with] the English lout in the Spanish airport, representing England in that kind of way. You know, the one who is oblivious to the Spanish culture and not behaving properly. I have Arab friends who say the same thing. Societies are all the same, in the sense that the vast majority of people are well behaved and cool, and then you have these different quirks.

In the context of this particular day at the airport: Nigerians have this real mistrust of authorities, so when the flight was cancelled ... there is always this suspicion that corruption lies behind it, not engine failure. You know, "someone at the top has done something". So that is where people's anger and frustration comes from. It is all very nuanced you know ... when you are at an airport, looking at an Italian looking at a bunch of Nigerians shouting. Those Nigerians were actually a minority. It was about 40 people making noise and everyone else keeping quiet. That was the worst thing, seeing this Italian getting this snapshot. He didn't understand the context behind it, so he revelled in a sense of superiority.

It is an anxiety every nationality suffers. You want the world to see you in all your nuanced variety, therefore it kills you when you are at an airport and people see you at a superficial level. It can be quite frustrating for a disaporan like me: you understand why the Italian thinks the way he does, yet you understand the Nigerians' behaviour too.

That sense of cultural conflict was with me at the start and never went away. Whether it was religion, or community versus individuality, or Nollywood, I would consider its good/bad points and assess my attitude towards it. I surprised myself by changing my outlook on certain issues. 
NH: The outsider perspective potentially puts the writer in a precarious position, because whatever you write can be read as culturally biased or unfair. The insider perspective on the other hand can be interpreted as a sign that one allows oneself to speak for the people who are described. You were born in Nigeria but live in London, and you write about a former British colony: did you experience this conflict when you wrote the book and if so, what were your strategies to negotiate it and make it possible to write the book at all?

$N S W$ : Travel writing is a very subjective genre, so when I am writing I'm expressing my personal point of view. That is why I always put my cultural biases on the table. But I think the "insider" versus "outsider" is a false dichotomy, in many ways. Most of my criticism and praise about Nigeria is similar to those made by Nigerians in Nigeria. There's often a double standard. I can criticise Nigeria, and then someone who was raised in Nigeria might take issue with my complaint. But then they issue the same criticism later on. I think this discussion about the "colonial viewpoint" is redundant if people are honest with themselves. They will see that a lot of my viewpoints are the same as theirs. So I just write what I wanted to write. When you start worrying about what and who you represent, it hampers your writing. There are going to be people who have this issue about "the colonised mind" $[\ldots]$

I think every book is individual. When it comes to African literature, there's a belief that it represents an entire continent. There is this pressure for writers to be all things to all readers. I have gone past that, because I know that no single book can achieve that aim. Transwonderland is simply my book, my journey and my point of view. It is $m y$ backstory. So I just write what I want and put my opinions [out] there.

$N H$ : Can you say something about your role in the text? It seems to me that in the book, the central subject (that is, you) oscillates between being an insider and an outsider. In several parts of the book you point out that people can somehow tell that you come from somewhere else even though you try to pass as a local. (At one point you write that "we're still convinced that the traditional, malevolent spirits are out to get us" [2012, 67], which to me implies that you do not actually believe this at all, though other Nigerians might.) Was this something you consciously wanted to write about when conceiving the book or was it just unavoidable?

$N S W$ : There were certain subjects I wanted to cover, but religion was not one of them. It was not an issue before I went out to Nigeria, but it became one, so I wrote about it. I wrote about whatever happened to me. For example, after Transwonderland was published someone asked me why I didn't write about women and feminism. I said, "Well, because it was not a massive issue for me personally during my trip". That is the thing about travelogues: even though you are writing about a country, you are not setting out to cover every aspect of it. I had my experiences, and I chose to cover topics that came off the back of those experiences. You weave it into the narrative.

So the [issue of religion] came after because it was all around one. Only people from the diaspora can really understand what it feels like to be Nigerian but also British or American, etc. So some people will say, why does she say "we". But to say "they" would not make sense because I would be divorcing myself from my heritage. I was born there. My parents are Nigerian, my grandparents are Nigerian. I grew up constantly being told I was Nigerian ("Don't go around thinking you are British".) I did not even have a British passport until I was 20. Plus, I believe you have to be consistent. You cannot say "we" sometimes and "they" at other times. Even though that is what you do in general: when you talk about aspects of a country that you disagree with or feel disconnected from, you tend to refer to people as "they". But it is best to be consistent. If you are going to say "we" on some occasions, then just use "we" all the time.

But certain Nigerians raised in Nigeria find it jarring. They say, "Why is she saying 'we' when she doesn't live here?" I think Americans understand my position. Italian-Americans describe themselves as being "Italian". Everyone knows what they mean by that, i.e. being both American 
and Italian. For us Nigerian diasporans it is the same thing, but our motherland roots are even closer. Many of us were born in Nigeria. So for me, being a member of the diaspora means you have a dual identity. Other diasporans understand where I am coming from. And they were the audience for my book.

$N H$ : You write at one point that you started to feel that you are a member of an ethnic minority group in Nigeria, like you are a member of a racial minority in the UK. How did this affect your perspective, if at all, on Nigeria?

$N S W$ : When you are in England, you are Nigerian, but when you are in Nigeria, you begin to identify more with your ethnic identity. It is important because I think my father's campaign was environmental and concerned with human rights, but there was an ethnic dimension to it. The major ethnic groups dominate Nigeria and we Ogonis are marginalised and exploited. I felt that much more strongly when I was out there.

I started to [identify with the Ogoni ethnic group] when I visited my home town towards the end of my journey. But for a large part of my trip I was just looking at various aspects of Nigeria as a traveller, not an Ogoni. When I was in the North there was a strong sense of being different. They are ethnically different, they look different and they have a different religion [Islam] and language [Hausa, primarily]. The fact that we both speak English is about the only thing we have in common. Up there I felt like a Southerner. When I went to my hometown, I heard people pronounce my name correctly. It is the only place on earth where that happens. It was really nice. That was when I really started to have a really strong sense of my ethnicity. Ethnicity plays such a huge role in the power structure and the fact that we as Ogonis are so marginalised is definitely something that bothers me now, more than it did before I took that trip.

\section{Reading and writing travel literature}

$N H$ : What did you do to remember details and conversations you had with people when travelling?

$N S W$ : It depends on where I was. If I was in a minibus or a taxi, or with my driver, I had a notepad and I would scribble down dialogue and note down the scenery. Sometimes I used a Dictaphone, which I used when it was quiet. Sometimes I would paraphrase if I did not note what they said and therefore could not quote them verbatim.

$N H$ : The reason I ask is that there has to be a certain level of artistic embellishment and invention involved in the writing process, I suppose. Journalism is one thing, but travel writing is perhaps different when it comes to how faithfully one reiterates conversations and so on.

$N S W$ : Well it is non-fiction, so the only creative part of the process is the writing style. I don't believe in embellishing. I try to be as faithful as possible. To me travel writing is still a form of journalism. That is why I paraphrase if I know I cannot remember quotes. If you cannot make it accurate, then you cannot pretend it is accurate. You just have to say, "this is kind of what they said", without putting it in quotes.

$N H$ : Do you read a lot of travel writing, and if so, what kind of books inspired you when you wrote Looking for Transwonderland?

NSW: The first travel book that really inspired me was Almost Heaven [:Travels Through the Backwoods of America, 1999], by Martin Fletcher. He was a newspaper journalist, but he travelled around the backwater parts of the US. That really excited me. I was at university and had not really come across that kind of writing before. I was reading textbooks and the occasional novel, and it had never occurred to me that you could combine travel with journalism. Then, while at journalism school in New York, one of my lecturers suggested that I read a book called Miami (1987) by Joan Didion, as an example of creative non-fiction. The way she wrote was even more literary than Fletcher's style and again, it just blew me away. I [thought] "This is amazing! This is 
exactly what I want to do". I always wanted to write, but I never felt I could write fiction. This kind of creative non-fiction - which I guess the Americans started - you know, Truman Capote and so on - opened my eyes to a whole new possibility. [...]

More recently, I have read Binyavanga Wainaina, the Kenyan writer. His book, One Day I Will Write about This Place (2011), is not a travel book, but there is an element of travel in it. He has also written [about travel] online. I came across him just after he won the Caine prize. I was amazed there was another African who wanted to do travel writing - I thought I was the only one! I love his writing. There is also the Togolese Tété-Michel Kpomassie. When I went to Togo in 1998 I came across his book, An African in Greenland (1981). It is the only book I had read of an African doing that sort of travel, voyaging outside of Africa purely for curiosity's sake. So I loved that, too. Then there have been other books that I haven't actually liked but stuck in my head. People like Keith Richburg, an African American guy. I disagreed with his views but it was an interesting insight: a guy who had a preconception about Africa and became totally disillusioned. That [book, Out of America, 1997] stuck in my head. In some sense [it] was a cautionary tale. You know, the importance of keeping an open mind and being aware of your prejudices as a writer. $[\ldots]$

$N H$ : In the book you discuss things like gender relations, capitalism and the politics of portrayal of Nigerian history. At one point you refer to Ghanaian philosopher Kwame Anthony Appiah and his postcolonial theories of cultural heritage. This adds an intellectual dimension to the general travel narrative and the personal, psychological narrative in the book. Apart from your more personal reasons to travel in Nigeria, did such intellectual interests have a part in your decision to write the book?

$N S W$ : When you travel anywhere, the history of the country is really important if you want to understand a country, how it ticks. So yes, that was important to me. I did not want to write a purely straightforward travel narrative. There is this intellectual side that I am interested in. I knew long before I wrote the book that I was going to incorporate [it]. But not the museum part with Appiah - that was borne out of my experience at the museum. However, the roots of corruption was an issue I knew I wanted to incorporate into the book beforehand.

$J R$ : I was just thinking about when you participated in a panel discussion at the literary festival "Africa Writes, 2014". You were on a panel entitled "Broadening the Gaze". The session chair, Fatimah Kelleher, who is in herself an acclaimed writer and commentator, compiled a list of "Ten Books for Your Shelf of African and African Diaspora Travel Writing" ${ }^{3}$ It was a mix of contemporary and historical figures, and rightly you appeared. Notably, however, you were the only woman. How do you see the role of gender in relation to travel writing and what the female gaze brings to the craft and experience of travel writing?

$N S W$ : I have read a lot of travel books by men, Western men from decades back. There is a gender divide, but I can't deconstruct what it is.

I generalise, but men are more likely to discuss [say] the design of an aircraft, or they will encounter a prostitute or something. These are the writers I don't like (the male writers I do like are great). [...] As a woman I would have all sorts of questions to ask [the prostitute], but some certain male writers gloss over those kind of things.

Also, gender and age are a big thing in Africa. The way people relate to you can differ according to your gender and age. Take someone like Paul Theroux, who is [74] years old, white and male. The way he interacts with people will be different from the way I interact with them. It is not necessarily for the worse. Men will open up to him in a way they might not to me - particularly in Muslim areas. Also, I find as a woman, certain men get boastful. They might exaggerate their exploits in a way they might not when talking to other men. Also, you [as a woman] can have conversations with teenage girls in a way that a 60-year-old man can't. So there are all sort of differences. Both sides are valid. For me, the plurality of voices is the most important thing. 
$N H$ : One thing that I noticed when reading the book is that you often apply an aesthetic perspective. To the extent that you are critical in the text, your critique is often expressed in aesthetic terms. For example, when after a particularly hard day you become "fed up with expensive inadequacy, fed up with unpredictability and low standards" this is triggered by a TV-programme that you describe as "garish" and cheap $(2012,198)$. At other points you admire the aesthetic aspects of places, things and situations more perhaps than other qualities that they may have. Would you say this is just a tendency that you have, or is it a matter of style and what kind of book you wanted to write?

$N S W$ : I guess I enjoy looking at beautiful things, but when you are talking about a screen being garish or about rubbish all over the street, it is not a superficial observation; it is symptomatic of something that is wrong. That cheap, garish, state-run TV-programme reflects the fact that our economy has not achieved its potential and there is not enough money. If there is rubbish all over the street it is symptomatic of weak government structures. So all my observations are rooted in something deeper.

$\mathrm{NH}$ : You use the notion of Africa sparingly in Looking for Transwonderland. Did you also consciously avoid going into the ideological complexities surrounding the notion of Africa?

$N S W$ : I did not really think about it. Nigeria was my focus and wherever I go, whatever books I write next, the focus will always be on the particular country I'm in. For me "Africa" is too big. A place like Malawi is too different and far removed from Nigeria. To me it is a continent, and that is about it. I have been to about twelve or thirteen [African] countries, and they are massively different [from each other]. When you are in Africa, in Africa as a continent, the notion is totally meaningless. It is only when you are in Europe, or anywhere outside the continent, that you speak of Africa in broad terms. When you are in it, to me, it does not mean anything much.

$N H$ : The reason I ask is that a person like Keith Richburg, for example, struggles with the concept and it becomes for him a huge problem because it seems to come with an outside-perspective. I do not see that in your book.

$N S W$ : It is probably because I see myself as a Nigerian.

$J R$ : Last year I had the opportunity to meet you for the first time at SCOLMA's [UK Library \& Archives Group on Africa] conference. You gave a keynote there and I remember you concluding with the contemplation that Africa in many respects keeps travel writing alive through its endless possibilities. In that thought is there something of a celebration of the contemporary genre of travel writing or travel literature itself? What views might emerge and what might some of those possibilities be?

$N S W$ : Me, I just write. There are different types of travel writing. When it comes to possibilities, imagine going to a village in Surrey and trying to write a travel narrative. You are there for three days. That compared to Africa would be very difficult. People do not hang out on the street. They are English, so they don't necessarily tell you things right up front.

There is a struggle. I am not saying English society is static by any means, but it is not as transient, as in transit, as Nigerian society. You look at Nigeria, you've got this feudalistic, almost medieval culture fused with modern cultures. You've got people who within one generation move from rural existence to driving a $4 \times 4$ in a city. You've got police corruption on a massive scale. There is more drama going on at the surface anyway. There is plenty of drama in England and society is changing in a lot of ways, but I just think that Africa lends itself to that kind of exciting travel narrative, in a way that a middle-class English small town doesn't and things are changing much more rapidly in Africa at the moment.

Every five years you go back and there have been massive, massive changes. It feels much more like a rollercoaster. Travel writing back in the eighteenth-century, it was just very easy for someone from England to go to another country and say, "These are their trees, these are their animals, this is what people wear" - these kind of superficial observations. You can't do 
that now, because everyone knows what everyone looks like and you have to dig deeper. I think it is very hard to dig deep in a society like England. In a small village in Surrey it is very, very hard, whereas in Nigeria the nuggets are just up there on the surface.

In terms of travel writing [Africa] is a new frontier in a way that societies in the West don't have. Here [in the UK], societies are a bit more stable. Things are changing and the shifts are still seismic, but somehow slower.

$J R$ : We've got two more questions ...

$N H$ : Can we ask you about your next project?

$N S W:$ Nh-nh!

$J R$ : I can't resist asking you a question of the [BBC Radio 4] Desert Island variety: if you found yourself as a castaway and had one wish for a book on your uninhabited island, what would it be?

$N S W$ : I want the kind of book that I could read over and over again without getting bored. A book that would make me laugh and that would make me think. My favourite ever is Bad Times in Buenos Aires (1999) by Miranda France. I just love it, because it is unashamedly subjective.

You know, she hates it there, but any sensible reader takes everything with a pinch of salt. The writing is just beautiful and, importantly, she predicted the collapse of Argentinian society around 1991. Many Argentinians, a lot like Nigerians, are a little huffy: "this English girl who comes here, talking about...", you know? But 10 years later, the economy collapsed. She [had] sensed the malaise in society and she was right in her observations. Yes, it isn't particularly nuanced, but it is really funny [... I I would take that book.

$J R$ : Thank you so much, Noo.

\section{Disclosure statement}

No potential conflict of interest was reported by the authors.

\section{Notes}

1. For more on the "African Intellectual Mobilities" colloquium at which the majority of this interview was recorded, see Remmington and Hållén (2015).

2. For the purpose of clarity, ellipses in this interview are marked thus [ ... ]. Places where sentences in the conversation were left unfinished are marked by three full stops without square brackets. Square brackets are used where information has been added by the interviewers.

3. http://whatsonafrica.org/african-and-african-diaspora-travel-writing-ten-books-and-narratives-for-yourshelf/ (accessed 1 June 2015).

\section{References}

Didion, Joan. 1987. Miami. New York: Simon \& Schuster.

Fletcher, Martin. 1999. Almost Heaven: Travels in the Backwoods of America. London: Abacus.

Frances, Miranda. 1999. Bad Times in Buenos Aires. Newark: Ecco.

Kpomassie, Tété-Michel. 1981. An African in Greenland. Translated by James Kirkup. San Diego: Harcourt Brace Jovanovitch.

Remmington, Janet, and Nicklas Hållén. 2015. “'Africa Travels, Africa Writes': Notes on African Intellectual Mobilities." Africa in Words, February 26. http://africainwords.com/2015/02/26/africatravels-africa-writes-notes-on-african-intellectual-mobilities/.

Richburg, Keith. 1997. Out of America: A Black Man Confronts Africa. London: Harcourt.

Saro-Wiwa, Noo. 2012. Looking for Transwonderland: Travels in Nigeria. London: Granta.

Wainaina, Binyavanga. 2011. One Day I Will Write About This Place: A Memoir. Minneapolis: Graywolf Press. 